\title{
POPULATION CHARACTERISTICS AND RECENT HISTORY OF LIONS IN TWO PARTS OF THE KRUGER NATIONAL PARK
}

\author{
G. L. SMUTS \\ Dept. of Nature Conservation \\ Private Bag X404 \\ Skukuza \\ 1350
}

Abstract - A survey entailing the capture and marking of lions was undertaken in two parts of the Kruger National Park, Republic of South Africa, during 1974 and 1975. A total of 347 lions were captured and marked while 62 were destroyed as part of an experimental cropping operation. Sixty out of 66 prides contained marked lions. The Central District (5 $560 \mathrm{~km}^{2}$ ) had a minimum population of 708 lions (60 prides) while the Crocodile Bridge area $\left(463 \mathrm{~km}^{2}\right)$ had 67 lions. Adult sex ratios differed between areas with a range of $1 \delta^{\top}: 1,7 \uparrow$ to $1 \sigma^{7}: 2,4 \uparrow$ and was density dependent. Sex ratios for all age classes together varied between $1 \delta: 1,4 \uparrow$ and $1 \delta: 1,7 \bigcirc(\mathrm{n}=591$ lions). Age composition for the Central District was: adults - 53,3\%; sub-adults - 17,1\%; large cubs $8,8 \%$; small cubs $-20,9 \%$ ( $\mathrm{n}=708$ lions). Lion density (all ages) ranged from 10,5 to 15,5 lions $/ 100 \mathrm{~km}^{2}$ while lion biomass ranged from 11,0 to $18,2 \mathrm{~kg} / \mathrm{km}^{2}$. Pride sizes ranged from four to 21 with a mean of 11,8 for the whole study area. Average number of adult males per pride was 2,1 with a maximum of five. Ten marked lions were destroyed outside the Park and part of one pride was migratory within the Park. The past and present distribution of prides and their sizes, indicated that the lion population had increased considerably and this increase could be correlated with an increase in the number of artificial waterholes and the stabilization of existing waterholes. Since 1933, 29 dams were built and 64 windmills erected in the study areas, with the number of lions and their prey populations more than doubling since this date.

\section{Introduction}

With the construction of the $500 \mathrm{~km}$ long western boundary fence of the Kruger National Park (KNP), Republic of South Africa, in 1961 and the new game proof fence on the east (completed early in 1976), it has become increasingly necessary to assess the status of the now enclosed 
game populations. Although most medium-sized and large herbivores are censused annually, comparable data for the larger carnivores are almost non existent. At the same time the status of certain ungulate populations has indicated that predation is a major factor influencing the growth of these populations. To gain a better insight into predatorprey relationships, it was decided to initially undertake a survey of the lions Panthera leo krugeri in the Central District and the Crocodile Bridge-Lower Sabi area of the KNP (Fig. 1). This survey was subsequently designed to take the form of a census while at the same time data could also be collected on characteristics relevant to the population dynamics, general distribution and movements of lions.

Due to the practical problems involved in censusing lions, there is relatively little published data on aspects such as density, biomass, sex and age composition of lion populations in large areas. The only really reliable data are those for small study areas such as the Nairobi National Park (Rudnai 1973) and the Ngorongoro Crater (Schaller 1972, Kruuk 1972), where individuals or groups could be identified. Other than these, population sizes have largely been estimated by a variety of unsatisfactory methods. More recently three rough survey methods were described for the eastern Selous Game Reserve by Rodgers (1974).

\section{Material and Methods}

The survey method employed is described in detail by Smuts, Whyte and Dearlove (1976), and entailed the capture and marking of lions from each group encountered. The areas surveyed were the Central District and the Crocodile Bridge-Lower Sabi area east of the Gomondwane tar road in the Southern District (Fig. 1). Two independent teams started the survey in the Mnondozi-Rietpan area (Fig. 1) during July 1974, gradually working northwards until the eastern half of the Central District had been covered. The western half was then done starting again in the south and working northwards towards the Olifants river. The Crocodile Bridge-Lower Sabi area was surveyed during March and April, the entire operation being completed in August 1975. In the case of groups of between one and five lions, it was endeavoured to mark all the individuals, while in larger groups between $50 \%$ and $80 \%$ were ear tagged.

To facilitate data analysis the Central District was divided into four areas as indicated in Fig. 1. These were chosen on the basis that considerable differences occur in each area with respect to both vegetation and game composition, especially the western and eastern halves of the Central District, while area (1) in the northwest differs from area (2) in that a large part of area (1) is dominated by Colophospermum mopane shrubs and trees. Zebra Equus burchelli antiquorum and wildebeest Connochaetes taurinus taurinus also migrate from area (1) to (2), spending the wet season in area (1) and the dry season in area (2) (Smuts 1974). On the eastern half of the Central District, zebra and wildebeest in area (3) are largely sedentary, while those in area (4) are migratory, undertaking 
a north-south movement each year (Smuts 1974). The Crocodile BridgeLower Sabi area is actually a continuation of area (4) and the eastern Lebombo Flats, but lies on the southern side of the perennial Sabi River where it forms a fairly closed unit for the game populations (Smuts 1974). The boundaries of each area were fitted after the approximate ranges of all the prides encountered had been plotted onto a map, thereby grouping the prides associated with each particular area.

Since entire prides were seldom captured on one night, different groups captured at the same locality on successive nights or in the same general area, were grouped and regarded as being one pride. Marked lions which were recaptured or resighted during the survey also assisted in the allocation of individuals or groups to a pride. Age composition was analysed by dividing all lions into the following age classes. Ages were assigned to classes by utlizing data published by Schaller (1972), Bertram (1973), Rudnai (1973) and personal observations on age determination and growth in the lion (Smuts, Anderson and Austin 1976):

(i) Adult males (4+ years old) - lions with a well developed mane and a body mass in excess of $170 \mathrm{~kg}$ (except in unusual cases or emaciated specimens). Adult males can also be identified to some extent by the greyer colour of their coat, while scars are often more numerous on the face. Behaviour at the carcass and particularly in the presence of other males also helps to distinguish adult males from large sub-adults. In In this group the longest cusps of the second upper $\left(\mathrm{P}^{3}\right)$ and lower $\left(\mathrm{P}_{4}\right)$ permanent premolars are worn (Smuts, Anderson and Austin 1976).

Adult females $(4+$ years old $)-$ females with a body mass in excess of $110 \mathrm{~kg}$ (except in some old and/or emaciated specimens). Only lionesses which had had one or more litters were regarded as adult. The prominently enlarged nipples distinguished these females from their nulliparous counterparts. Tooth wear is similar to that for adult males.

(ii) Sub-adult males (2-4 years old) - lions varying in mass from about $100 \mathrm{~kg}$ to almost 180 kilogram. Here the mane is incompletely developed while the incisors and the second upper premolar $\left(\mathrm{P}^{3}\right)$ start wearing at about four years of age (Smuts, Anderson and Austin 1976).

Sub-adult females (2-4 years old) - females varying in mass from about $75 \mathrm{~kg}$ to $120 \mathrm{kilogram}$. Tooth wear is similar to that for sub-adult males.

(iii) Large cubs (1-2 years old) - lions varying in mass from about 50 to 90 kilogram. Between 12 and 14 months of age the permanent canines erupt (Smuts, Anderson and Austin 1976). These lions, both male and female, were separated from the small cubs either by estimating or actually measuring body mass and by examining their dentition.

(iv) Small cubs (0-1 year old) - lions with a body mass of less than 50 kilogram.

Using measurements of mass taken from some 89 lions during the study, together with those of five known-age specimens, the following average body masses were calculated for their corresponding age classes. 
These measurements were used to calculate lion biomass for each part of the study area. In all instances average body mass includes stomach fill: adult males ( $181 \mathrm{~kg} ; \mathrm{n}=14)$; adult females ( $126 \mathrm{~kg} ; \mathrm{n}=25)$; sub-adult males ( $146 \mathrm{~kg} ; \mathrm{n}=25)$ and sub-adult females ( $103 \mathrm{~kg} ; \mathrm{n}=11$ ). For cubs, rough growth curves were plotted and the following average body masses used for each age class; male cubs (1-2 years) $(77 \mathrm{~kg})$; female cubs ( $1-2$ years) ( $60 \mathrm{~kg}$ ); cubs (8-12 months) (44 kg); cubs (6-8 months) (30 kg); cubs (4-6 months) (22 kg); cubs (0-2 months) (5 kg).

The recent history(1902-1956) of the two lion populations was studied by utilizing the following information: annual reports compiled since 1903 by the respective wardens in the Sabi Game Reserve and later the Kruger National Park; maps compiled by rangers during 1956 illustrating the distribution and sizes of prides in the two study areas. Since the provision of artificial waterholes in the form of dams and windmills as well as the stabilization of natural waterholes by man appeared to be important in influencing the distribution and numerical status of game populations in the areas surveyed, these programs, initiated in 1933, were studied in relation to the colonisation of new areas by herbivore and predator populations (Smuts 1975).

\section{Results}

During the survey a total of 347 lions were captured and marked while 141 of the marked lions were also recaptured. Of the 347,319 were marked in the Central District (45\% of the population) while 62 were additionally destroyed as part of an experimental cropping operation (Fig. 1). In the Crocodile Bridge-Lower Sabi area 28 were marked ( $42 \%$ of the population).

All but three of the 60 prides in the Central District contained marked lions while three out of six in the Crocodile Bridge-Lower Sabi area were marked. Final survey results indicated that the Central District had a minimum population of 708 lions (Fig. 1), while the Crocodile Bridge-Lower Sabi area had 67 lions. The composition of individual prides is described in a separate memorandum (Smuts 1975), while Table 1 summarises relevant data on sex ratio, age composition, lion density and lion biomass per area. Mean pride sizes and average number of adult females per pride and area are given in Tables 2 and 3 respectively.

Modal pride size for the Central District was nine. The maximum number of adult males in one pride and definitely associating together, was five for pride 26 in the Central District. Modal number of adult males per pride for the Central District was two, the average being 2,1. All sex ratios differed significantly from the expected $1: 1$ ratio with chi-square values increasing from 4,0 (area 1 - all ages) to 22,0 (Central District - all ages).

By the time the survey had been completed it was noted that the females and young of one pride were migratory (Fig. 1), following the 
Table 1

Population characteristics, density and biomass for lions from the Central District and the Crocodile Bridge-Lower Sabi are of the Kruger National Park

\begin{tabular}{|c|c|c|c|c|c|c|c|c|c|c|c|c|c|c|}
\hline \multirow[b]{2}{*}{$\begin{array}{l}\text { Area as per } \\
\text { Fig. } 1\end{array}$} & \multicolumn{4}{|c|}{ Sex Ratio } & \multicolumn{6}{|c|}{ Age Composition of Population (\%) } & \multicolumn{4}{|c|}{ Lion Density per $100 \mathrm{~km}^{2}$} \\
\hline & Adults & $\begin{array}{l}\text { Sub- } \\
\text { adults }\end{array}$ & $\begin{array}{l}\text { and Sub- } \\
\text { adults }\end{array}$ & $\begin{array}{l}\text { All } \\
\text { Ages }\end{array}$ & Adults & $\begin{array}{l}\text { Sub- } \\
\text { adults }\end{array}$ & $\begin{array}{l}\text { Large } \\
\text { Cubs }\end{array}$ & $\begin{array}{l}\text { Small } \\
\text { Cubs }\end{array}$ & $\begin{array}{l}\text { Adults } \\
\text { and Sub- } \\
\text { adults }\end{array}$ & Cubs & $\begin{array}{c}\text { Area } \\
\left(\mathrm{km}^{2}\right)\end{array}$ & $\begin{array}{c}\text { All } \\
\text { Ages }\end{array}$ & $\begin{array}{l}\text { Adults } \\
\text { and Sub- } \\
\text { adults }\end{array}$ & $\begin{array}{l}\text { Biomass } \\
\left(\mathrm{kg} / \mathrm{km}^{2}\right)\end{array}$ \\
\hline 1 & $\begin{array}{c}10^{\pi}: 1,7 \% \\
25: 43\end{array}$ & $\begin{array}{c}1 \delta^{-7}: 1,5 \% \\
6: 9\end{array}$ & $\begin{array}{c}10^{\pi}: 1,7 \% \\
31: 52\end{array}$ & $\begin{array}{c}10^{-}: 1,5 \text { q } \\
40: 60\end{array}$ & $\begin{array}{c}49,3 \\
\mathrm{n}=68\end{array}$ & $\begin{array}{c}10,9 \\
\mathrm{n}=15\end{array}$ & $\begin{array}{c}13,8 \\
\mathrm{n}=19\end{array}$ & $\begin{array}{c}26,1 \\
\mathrm{n}=36\end{array}$ & $\begin{array}{c}60,1 \\
n=83\end{array}$ & $\begin{array}{c}39,9 \\
\mathrm{n}=55\end{array}$ & 1310,0 & $\begin{array}{c}10,5 \\
n=138\end{array}$ & $\begin{array}{c}6,3 \\
\mathrm{n}=83\end{array}$ & 11,0 \\
\hline 2 & $\begin{array}{c}10^{\pi}: 2,1 \% \\
24: 50\end{array}$ & $\begin{array}{c}10: 0,8 \text { ? } \\
11: 9\end{array}$ & $\begin{array}{c}10: 1,7 \% \\
35: 59\end{array}$ & $\begin{array}{c}10: 1,7 \text { ? } \\
35: 61\end{array}$ & $\begin{array}{c}55,1 \\
\mathrm{n}=76\end{array}$ & $\begin{array}{c}14,5 \\
n=20\end{array}$ & $\begin{array}{c}5,8 \\
\mathrm{n}=8\end{array}$ & $\begin{array}{c}24,6 \\
\mathrm{n}=34\end{array}$ & $\begin{array}{c}69,6 \\
\mathrm{n}=96\end{array}$ & $\begin{array}{c}30,4 \\
n=42\end{array}$ & 1176,0 & $\begin{array}{c}11,7 \\
n=138\end{array}$ & $\begin{array}{c}8,2 \\
\mathrm{n}=96\end{array}$ & 12,5 \\
\hline 3 & $\begin{array}{c}10: 1,9 \text { ? } \\
32: 61\end{array}$ & $\begin{array}{c}10: 0,3 \text { ? } \\
15: 5\end{array}$ & $\begin{array}{c}1 ठ: 1,4 \text { ? } \\
47: 66\end{array}$ & $\begin{array}{c}1 \sigma^{7}: 1,5 \text { Q } \\
47: 70\end{array}$ & $\begin{array}{c}60,4 \\
n=20\end{array}$ & $\begin{array}{l}13,0 \\
n=5\end{array}$ & $\begin{array}{c}3,3 \\
n=36\end{array}$ & $\begin{array}{c}23,4 \\
n=113\end{array}$ & $\begin{array}{c}73,4 \\
n=113\end{array}$ & $\begin{array}{c}26,6 \\
\mathrm{n}=41\end{array}$ & 1276,0 & $\begin{array}{c}12,1 \\
n=154\end{array}$ & $\begin{array}{c}8,9 \\
n=113\end{array}$ & 13,9 \\
\hline 4 & $\begin{array}{c}10^{\pi}: 2,4 \% \\
41: 97\end{array}$ & $\begin{array}{c}1 \delta^{-5}: 0,5 \text { q } \\
45: 21\end{array}$ & $\begin{array}{c}10: 1,4 q \\
86: 118\end{array}$ & $91: 130$ & $\begin{array}{c}50,4 \\
\mathrm{n}=140\end{array}$ & $\begin{array}{c}23,7 \\
\mathrm{n}=66\end{array}$ & $\begin{array}{c}10,8 \\
\mathrm{n}=30\end{array}$ & $\begin{array}{c}15,1 \\
n=42\end{array}$ & $\begin{array}{c}74,1 \\
n=206\end{array}$ & $\begin{array}{c}25,9 \\
\mathrm{n}=72\end{array}$ & 1798,0 & $\begin{array}{c}15,5 \\
n=278\end{array}$ & $\begin{array}{c}11,5 \\
n=206\end{array}$ & 17,7 \\
\hline $\begin{array}{l}1 \text { and } 2 \\
\text { (Western } \\
\text { Boundary } \\
3 \text { and } 4\end{array}$ & $\begin{array}{c}107: 1,9 \text { Q } \\
49,94\end{array}$ & $\begin{array}{c}10: 1,19 \\
17: 18\end{array}$ & $\begin{array}{c}10: 1,7 \uparrow \\
66: 111\end{array}$ & $\begin{array}{c}10: 1,69 \\
75: 121\end{array}$ & $\begin{array}{c}52,2 \\
n=144\end{array}$ & $\begin{array}{c}12,7 \\
n=35\end{array}$ & $\begin{array}{c}9,8 \\
\mathrm{n}=27\end{array}$ & $\begin{array}{c}25,4 \\
\mathrm{n}=70\end{array}$ & $\begin{array}{c}64,9 \\
n=179\end{array}$ & $\begin{array}{c}35,1 \\
\mathrm{n}=97\end{array}$ & 2486,0 & $\begin{array}{c}11,1 \\
n=276\end{array}$ & $\begin{array}{c}7,2 \\
n=179\end{array}$ & 11,7 \\
\hline $\begin{array}{l}\text { Eastern } \\
\text { Boundary } \\
\text { Crocodile }\end{array}$ & $\begin{array}{c}10^{7}: 2,29 \\
73: 158\end{array}$ & $\begin{array}{c}10: 0,49 \\
60: 26\end{array}$ & $\begin{array}{l}10: 1,4 \% \\
133: 184\end{array}$ & $138: 200$ & $\begin{array}{c}53,9 \\
\mathrm{n}=233\end{array}$ & $\begin{array}{c}19,9 \\
\mathrm{n}=86\end{array}$ & $\begin{array}{c}8,1 \\
n=35\end{array}$ & $\begin{array}{c}18,1 \\
n=78\end{array}$ & $\begin{array}{c}73,9 \\
n=319\end{array}$ & $\begin{array}{c}26,2 \\
n=113\end{array}$ & 3074,0 & $\begin{array}{c}14,1 \\
n=432\end{array}$ & $\begin{array}{c}10,4 \\
n=319\end{array}$ & 16,1 \\
\hline $\begin{array}{l}\text { Bridge- } \\
\text { Lower Sabi }\end{array}$ & $\begin{array}{c}10: 2,29 \\
13: 29\end{array}$ & $\begin{array}{c}10: 0,69 \\
5: 3\end{array}$ & $\begin{array}{c}10: 1,89 \\
18: 32\end{array}$ & $\begin{array}{c}10: 1,59 \\
24: 87\end{array}$ & $\begin{array}{c}62,7 \\
n=42\end{array}$ & $\begin{array}{c}17,9 \\
n=12\end{array}$ & $\begin{array}{c}16,4 \\
n=11\end{array}$ & $\begin{array}{c}3,0 \\
\mathrm{n}=2\end{array}$ & $\begin{array}{c}80,6 \\
n=54\end{array}$ & $\begin{array}{c}19,4 \\
n=18\end{array}$ & 463,0 & $\begin{array}{r}14,5 \\
\mathrm{n}=67\end{array}$ & $\begin{array}{c}11,7 \\
\mathrm{n}=54\end{array}$ & 18,2 \\
\hline $\begin{array}{l}1 \& 2 \& 3 \& 4 \\
\text { (Central } \\
\text { District) }\end{array}$ & $\begin{array}{c}1 \sigma^{7}: 2,1 \text { Q } \\
122: 251\end{array}$ & $\begin{array}{c}10: 0,6 \text { 우 } \\
77: 44\end{array}$ & $\begin{array}{l}1 \sigma^{\pi}: 1,59 \\
199: 295\end{array}$ & $\begin{array}{l}1 \sigma^{7}: 1,5 q \\
211: 319\end{array}$ & $\begin{array}{c}53,3 \\
\mathrm{n}=377\end{array}$ & $\begin{array}{c}17,1 \\
n=121\end{array}$ & $\begin{array}{c}8,8 \\
n=62\end{array}$ & $\begin{array}{c}20,9 \\
n=148\end{array}$ & $\begin{array}{c}70,3 \\
n=498\end{array}$ & $\begin{array}{c}29,7 \\
n=210\end{array}$ & 5560,0 & $\begin{array}{c}12,7 \\
n=708\end{array}$ & $\begin{array}{c}9,0 \\
n=498\end{array}$ & 14,1 \\
\hline
\end{tabular}


Table 2

Mean pride sizes for lions from the Central District and the Crocodile BridgeLower Sabi area of the Kruger National Park

\begin{tabular}{|c|c|c|c|c|}
\hline Area as per Fig. 1 & $\begin{array}{l}\text { Number of } \\
\text { Prides }\end{array}$ & $\begin{array}{l}\text { Number of } \\
\text { Lions }\end{array}$ & $\begin{array}{l}\text { Mean Pride } \\
\text { Size }\end{array}$ & Range \\
\hline 1 & 13 & 138 & 10,6 & 4 to 18 \\
\hline 2 & 12 & 138 & 11,5 & 9 to 18 \\
\hline 3 & 12 & 154 & 12,8 & 7 to 21 \\
\hline 4 & 23 & 278 & 12,1 & 7 to 21 \\
\hline $\begin{array}{l}1 \text { and } 2 \text { (Western } \\
\text { Boundary } \\
3 \text { and } 4 \text { (Eastern }\end{array}$ & 25 & 276 & 11,0 & 4 to 18 \\
\hline $\begin{array}{l}\text { Boundary) } \\
\text { Crocodile Bridge- }\end{array}$ & 35 & 432 & 12,3 & 7 to 21 \\
\hline Lower Sabi & 6 & 67 & 11,2 & 6 to 16 \\
\hline $\begin{array}{l}1 \text { and } 2 \text { and } 3 \text { and } 4 \\
\text { (Central District) }\end{array}$ & 60 & 708 & 11,8 & 4 to 21 \\
\hline
\end{tabular}

Table 3

Average number of adult females per pride for lions from the Central District and Crocodile Bridge-Lower Sabi area of the Kruger National Park

\begin{tabular}{|c|c|c|c|c|}
\hline Área as per Fig. 1 & $\begin{array}{l}\text { Number of } \\
\text { Prides }\end{array}$ & $\begin{array}{l}\text { Number of } \\
\text { Adult } \\
\text { Females }\end{array}$ & $\begin{array}{c}\text { Average } \\
\text { Number of } \\
\text { Adult } \\
\text { Females }\end{array}$ & Range \\
\hline 1 & 13 & 43 & 3,3 & 2 to 5 \\
\hline 2 & 12 & 51 & 4,3 & 2 to 6 \\
\hline 3 & 12 & 61 & 5,1 & 2 to 8 \\
\hline 4 & 23 & 98 & 4,3 & 2 to 9 \\
\hline $\begin{array}{l}1 \text { and } 2 \text { (Western } \\
\text { Boundary) } \\
3 \text { and } 4 \text { (Eastern }\end{array}$ & 25 & 94 & 3,8 & 2 to 6 \\
\hline $\begin{array}{l}\text { Boundary) } \\
\text { Crocodile Bridge- }\end{array}$ & 35 & 159 & 4,5 & 2 to 9 \\
\hline Lower Sabi & 6 & 29 & 4,8 & 3 to 8 \\
\hline $\begin{array}{l}1 \text { and } 2 \text { and } 3 \text { and } 4 \\
\text { (Central District) }\end{array}$ & 60 & 253 & 4,2 & 2 to 9 \\
\hline
\end{tabular}


herds of zebra and wildebeest onto the Lindanda Plains, a distance of some $45 \mathrm{~km}$. The males, by contrast, stayed behind in the Mnondozi area. Excluding the migratory group and a few individuals from pride 5 (Fig. 1), all prides have so far remained in the same general area. The movements of a few sub-adult males and sub-adult females were rather erratic and they moved distances of up to $20 \mathrm{~km}$ in one or two days. A number of marked lions have moved out of the KNP (Fig. 1) and of these 10 are known to have been shot - three sub-adult males and two adult females on cattle farms in Mocambique, two adult females on a game farm near Komatipoort, two adult females on a farm near Crocodile Bridge and one adult female on a cattle farm near Klaseri. Last mentioned had moved a distance of $70 \mathrm{~km}$ from her original site of capture at Ngwenyeni Dam in the Central District.

Annual reports (Stevenson-Hamilton 1903-1945) indicate that since the first warden entered the Sabi Game Reserve (a section of the now Kruger National Park) in 1902, there have been marked increases in the numbers of most medium and large-sized herbivores. Prior to this time, however, and in particular towards the end of the 19th century, game populations in the eastern Transvaal Lowveld were in very poor state. This condition could largely be ascribed to the appalling slaughter of game perpetrated by indigenous bantu tribes, pioneer white hunters as well as members of the armed forces during the Anglo Boer War of 1899-1902. In addition, the Rinderpest epizootic of 1896-98 dealt a very decisive blow, severly reducing the numbers of most animals, but in particular of species such as the buffalo Syncerus caffer, kudu Tragelaphus strepsiceros and eland Taurotragus oryx (Stevenson-Hamilton 1925).

During 1903 Col. Stevenson-Hamilton estimated that there were only a few lions in the Reserve. However, from that year onwards game animals were afforded considerable protection from hunters, with the result that populations gradually increased. In 1925 the lion population for the Central District was estimated at 250 and by 1956 the estimate was 424 .

The history of the artificial water for game program (Smuts 1975) indicated that between 1933 and 1974 a total of 25 dams were built and 62 windmills erected in the Central District. Over the same period four dams were built and two windmills erected in the Crocodile BridgeLower Sabi area. Although the early lion surveys were carried out less intensively than the present ones, it could be established that at least 12 new prides ( $\mathrm{n}=159$ lions) had been formed since 1956 in the Central District. These were prides 7, 8, 10, 20, 21, 22, 23, 26, 32, 49, 50 and 53 (Fig. 1). Eight of these (prides 8, 21, 22, 23, 26, 49, 50 and 53) could be associated directly with the provision of new waterholes or the stabilization of existing ones. In the Crocodile Bridge-Lower Sabi area two prides ( $\mathrm{n}=27$ lions) were formed after 1956 in the vicinity of Mhlanganzwane and Mpanamana dams which were completed during 1956 and 1957 respectively. 


\section{General}

Although six of the 66 prides in the two study areas did not contain marked individuals, only three of these were not seen by the capture teams. These prides were, however, located audibly and their approximate sizes obtained from the respective game rangers living in each area. The estimated activity area for each pride was based on a limited number of resightings, information obtained from game rangers and on the relative distribution of surrounding prides. These areas overlap considerably and Fig. 1 should be regarded as a schematic rather than a true representation of each pride's activity area.

Although the survey is regarded as a reliable total count, the populations of 708 and 67 lions for each area are minimum figures since the possibility exists that a few small groups and females with small cubs could have been overlooked. It is not possible to estimate the magnitude of the error although this is believed to be insignificant for the following reasons: numerous ground observations have failed to report on large groups without marked individuals; in areas where the survey overlapped with itself and in one area (Bangu-Balule) which was re-surveyed, new results were in very close agreement with those of the initial surveys. The greatest source of error is due to "edge-effect" since certain of the peripheral prides may regularly move further out of the KNP than is presently known. Similarly other groups may also move into the Park more frequently than is realized. Movements towards the east will now, however, be almost impossible unless the lions scale the new 2,4 m high game proof fence, or leave via a few deep ravines which could not be adequately fenced. On the west lions can move fairly freely to and from the KNP by passing underneath or between strands of barbed wire of the game deterrent fence. All lions which were destroyed outside the eastern border of the Park left before the new fence was erected.

\section{Population characteristics, density and biomass}

Sex ratios (Table 1) indicate that in all areas there is a preponderance of females with the most distorted adult sex ratio being found in area (4) $\left(10^{\top}: 2,4 \%\right.$ ).

Areas with the most distorted adult sex ratios also had the lowest percentages of cubs. This was particularly so in area (4) and in the Crocodile Bridge-Lower Sabi area. Since a distorted sex ratio indicates a differential sex specific mortality rate, data in Table 1 indicate that lions on the eastern half of the Central District (areas (3) and (4)) as well as those in the Crocodile Bridge-Lower Sabi area ( a similar habitat to area (4)), have experienced the highest mortality rates. Because areas with the highest density of adult lions (Table 1) have the most distorted adult sex ratios, it would appear that adult sex ratio is density dependent and probably the result of intra-specific competition. Unfortunately insufficient cubs were sexed $\left(20 \delta^{\top} \sigma^{\star}: 26 q \%\right)$ to be able to make reliable conclu- 
sions on the age at which sex ratio starts to become distorted. In captivity, however, sex ratio at birth is parity (Brand $1963-131 \sigma^{\top} \sigma^{\star}: 130 \uparrow q$ ). Schaller (1972) also found that the sex ratio in cubs under one year of age was equal. It is very likely therefore that a differential mortality rate starts operating at about two years of age, when lions become independent (Rudnai 1973). It may, however, start even earlier since signs of growing independence and the beginnings of the male pattern of behaviour begin to show at about nine months of age (Rudnai op cit.). When studying sub-adult sex ratios (Table 1) and principally those for the western and eastern halves of the Central District the above type of pattern does not seem to apply. Here, for example, the Western Boundary area (areas (1) and (2)) had a sub-adult sex ratio of $1 \delta^{\mathrm{T}}: 1,1 \%(\mathrm{n}=35$ lions) while that for the Eastern Boundary area (areas (3) and (4)) was $10^{\pi}: 0,4 \%$ ( $\mathrm{n}=86$ lions). These differences seem to indicate that there may not be a gradual reduction in the number of young males relative to females after about nine months of age, but rather that there is a sudden reduction at a certain age and under specific conditions. Assuming that the distorted sub-adult sex ratio for the Eastern Boundary area is due to an elevated mortality rate of sub-adult females relative to males, it is possible that the males will show a similar high mortality when they start competing with adult males and that this will continue until the sex ratio is eventually distorted in favour of adult females as was found in all the areas studied (Table 1). The possibility that sub-adult lions disperse at different rates to and from the western and eastern halves of the Central District (due to conditions outside the Park) and the small size of each sample, however, precludes further speculation.

Sex ratios in the present study were more distorted than those found by Schaller (1972) for the Serengeti and particularly so for the adult plus sub-adult group where he obtained figures of between $1 \sigma^{\pi}: 1,1 q$ and

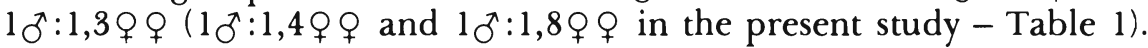
Here the lower lion density for the Serengeti ecological unit $( \pm 7,8$ lions/ $100 \mathrm{sq} \mathrm{km}$ - Schaller 1972) when compared with the Central District $(12,7$ lions/100 sq $\mathrm{km})$ supports the previous idea that sex ratio and therefore mortality rate is density dependent.

The age composition of the lions in the various areas also shows important differences (Table 1). Here the proportion of cubs decreases as density increases, the lowest percentage being found in area (4) and the Crocodile Bridge-Lower Sabi area. Area (1) had the highest percentage of cubs. These differences indicate that lions in the western half of the Central District and particularly in area (1), were increasing relative to those in the savannah areas on the east. On a long-term basis; however, lions on the east are more successful than those on the west as is indicated by data on density and biomass (Table 1), mean pride sizes (Table 2) and the number of adult females per pride (Table 3 ).

The fact that area (1) had 14\% more cubs than area (4) is striking since both areas were surveyed during the month of July although in two suc- 
cessive years. The low percentage of cubs in area (4) and the Crocodile Bridge-Lower Sabi area, together with the emigration of lions from these areas, indicate that food supply is possibly becoming a limiting factor. Six of the nine lions which have left the KNP via the eastern boundary have been adult females.

Since it was not always possible to ascertain the exact social status of all lions allocated to a particular pride, except when the entire pride was captured together on one night, pride sizes are slightly suspect. In certain cases resightings of marked lions and those recaptured did, however, help in the allocation of individuals to a particular pride. For these reasons the word "pride" has been used in preference to "group" although the limitations are realized.

Mean pride sizes (Table 2) indicate that the prides on the eastern half of the Central District are larger than those on the west, the largest mean being for area (3) and the smallest for area (1). The two largest prides $(\mathrm{n}=21$ lions each) were also recorded on the east (Fig. 1). Schaller (1972) obtained a mean pride size of 15,1 (range $=4$ to 37 ) for 14 prides whose size was determined accurately i.e., prides which were known to have retained their identity for at least one year. Data collected in both study areas (Tables 1 and 2) indicate that mean pride size is not density dependent. It is quite likely therefore, that food availability in the long term, is the regulating force. This is supported by the higher density of prey animals on the eastern half of the Central District than on the west (Smuts 1975).

Since the number of cubs in a pride may cause its size to change considerably from year to year, Bertram (1973) found that the most useful measure of pride size was the number of adult females. Using this criterion it can be seen (Table 3 ) that the largest mean pride size was recorded for area (3) on the eastern half of the Central District, followed by the Crocodile Bridge-Lower Sabi area. The largest number of adult females per pride came from areas (3), (4) and Crocodile Bridge-Lower Sabi. These data indicate that lions in the eastern areas have a greater reproductive potential than those on the west. When comparing mean pride sizes using adult females only, area (3) plus (4) has a reproductive potential $15,6 \%$ greater than area (1) plus (2).

Data presented in Table 1 indicate that by retaining the present population of 251 adult females in the Central District, but increasing cub percentages in areas (2), (3) and (4) to that of area (1), where $40 \%$ of the population are under two years of age, would cause the overall lion population in the Central District to rise from 708 to 819 . Compared to the Nairobi National Park where $60 \%$ of the lion population is under two years of age (Rudnai 1973), it is clear that the present population is below its potential maximum. The high percentage of adults and subadults in area (4), the distorted sex ratio of adults together with the fact that two marked males have been killed in fights and a number of adults shot outside the KNP in a relatively short time, indicate that in some areas at least, the population is on the decline. In conclusion therefore, 
most evidence, scanty as it may be, points to a lion population which has already reached its asymptote. This is supported by the results obtained from a series of intensive vehicle counts conducted since 1968. These counts (Smuts 1975) indicate that the lion population in the Central District reached its peak between 1971 and 1973 when there were some 825 lions.

\section{History of the lion population in the Central District}

Bearing in mind that regulation of a lion population is influenced both by food and sociai behaviour (Bertram 1973 and 1975) and that each pride occupies a fairly exclusive territory, the boundaries of which change little in the long term (Bertram 1973), it seems safe to say that a vast and lasting increase (50\% or more) in the size of a lion population in a large area, would require the settlement of unoccupied areas by new prides, with or without the increase in size of existing prides. This is apparently what has occurred in the Central District where in all probability the lion population has more than doubled during the past 50 years.

By studying the maps on pride distribution and sizes compiled during the 1956 lion survey in the Central District and Crocodile Bridge-Lower Sabi area and comparing these with Fig. 1, it was possible to correlate upward trends in the lion population with the provision of artificial waterholes and with stabilization of permanent drinking spots. The distribution of prides indicated that new prides had colonised areas where water had been provided and where sedentary prey species had consequently settled. It was concluded (Smuts 1975) that the increase in the lion population since 1925 had taken place gradually as prey populations increased and despite moderate cropping of lions up until 1958. The most dramatic increase, however, probably took place after 1933 when the first borehole was sunk and as the artificial water for game program gradually gained momentum, thereby opening up more and more areas for herbivore and carnivore colonisation.

\section{Acknowledgements}

The National Parks Board of Trustees are thanked for facilities provided and for permission to publish this paper. Mr I. J. Whyte and $\mathrm{Mr}$ T. W. Dearlove are thanked for their enthusiastic field assistance as are Messrs. A. J. Espag, J. Steyn, J. Clarke, J. P. Ackerman, B. P. Lamprechts, J. H. de Kock, P.Chauke, L. Mangane, M. Singwane, J. Sithole and P. Nkuna. Mr S. C. J. Joubert is thanked for advice and indirect assistance received during the study. 


\section{REFERENCES}

BERTRAM, B. C. R. 1973. Lion population regulation E. Afr. Wildl. J., $11: 215-225$.

BERTRAM, B. C. R. 1975. The social system of lions. Scientific American, April: 54-65.

BRAND, D. 1963. Records of mammals bred in the National Zoological Gardens of South Africa during the period of 1908 to 1960. Proc. Zool. Soc. Lond., 140:617-59.

KRUUK, H. 1972. The spotted hyena. A study of predation and social behaviour. Ed. G. B. Schaller, Chicago and London: The Univ., of Chicago Press.

RODGERS, W. A. 1974. The lion (Panthera leo, Linn) population of the eastern Selous Game Reserve. E. Afr. Wildl.J., 12:313-317.

RUDNAI, Judith. 1973. Reproductive biology of lions (Panthera leo massaica Neumann) in Nairobi National Park. E. Afr. Wildl. J., 11:241253.

SCHALLER, G. B. 1972. The Serengeti Lion. A study of predator prey relations. Ed. G. B. Schaller. Chicago and London: The Univ. of Chicago Press.

SMUTS, G. L. 1974. Game movements in the Kruger National Park and their relationship to the segregation of sub-populations and the allocation of culling compartments. J. sth. Afr. Wildl. Mgmt Ass., 4: $51-58$.

SMUTS, G. L. 1975. Predator prey relationships in the Central District of the Kruger National Park with emphasis on wildebeest and zebra populations. Memorandum, National Parks Board of Trustees, Pretoria. 74 pp.

SMUTS, G. L., J. L. ANDERSON and J. C. AUSTIN. 1976. Age determination and growth in the African lion (Panthera leo) (in prep.).

SMUTS, G. L., I. J. WHYTE and T. W. DEARLOVE. 1976. A mass capture technique for lions. E. Afr. Wildl.J., (in press).

STEVENSON-HAMILTON, J. 1903-1945. Annual reports of the Warden of the Kruger National Park, National Parks Board of Trustees, Pretoria. 